\title{
Synthesis of Polynuclear Heterocyclic Compounds Derived from 1-Biphenyl-4-yl-4-(1-methyl-1H-benzimidazol-2-yl)-But-2-en-1- One with Expected Biological Activity
}

\author{
N. A. Mahmoud ${ }^{1}$, Inas Ezz Eldin Islam ${ }^{1}$ and Enas A. Hasan ${ }^{2}$ \\ ${ }^{1}$ Chemistry Department, Faculty of Science (Girls),Al-Azhar University, Nasr City, and \\ ${ }^{2}$ Egyptian Organization for Biological Products \& Vaccines (Vacsera), Cairo Egypt
}

UCLEOPHILIC addition of barbituric acid, thioglycolic acid with malononitrile and
3-Amino-5-pyrazolinone with 1-Biphenyl-4-yl-4-(1-methyl-1H-benzimidazol-2-yl)- but-2-
en-1-one (1) gives pyrimidine, Thiazol and pyrazolinone derivatives (2-4), repectively.

Compound 4 which reacted with Arylidene malononitrile in ethanol to give pyrano derivatives (5).

Cyclocondensation of chalcone (1) with thiourea under reflux in ethanolic $\mathrm{NaOH}$ led to thiazine derivative (6) and treatment of (6) with bromine-acetic acid mixture afforded compound (7) similarly, cyclization of chalcone (1) with orthophenylinediamine in Dimethylformamide (DMF) gave diazepine derivatives (8).

Also, chalcone (1) reacted with 3-Amino-5-pyrazolinone in ethanol to give pyrazolinone derivative (9). (Scheme 1).

The condensation of compound (1) with 2- cyanoacetohydrazide through the acid-catalyzed reaction to form the Schiff base (10) by heating in $96 \%$ acetic acid gave the diazetidine derivative (11) which upon reaction with phosphorous oxychloride gave the chlorodiazetidine derivative (12), the latter compound reacted with 2ry amines and yielded the substitueted amino diazetidine derivatives $\left(13_{\mathrm{a}-\mathrm{c}}\right)$.

On the other hand, the Schiff bases (14) produced from condensed compound (1) with 2-Amino-2-(hydroxy methyl) propane-1,3-diol in ethyl alcohol which reacted with phosphorous oxychloride gave the propanol derivatives (15).

Finally, the cyclization reaction of compound (1) with 2-aminophenol and 2-aminothiophenol in dry benzene formed compounds $(16,17)$, repectively.(Scheme 2$)$.

\section{Introduction}

Benzimidazole derivatives are of wide interest because of their diverse biological activity and clinical application [1]. This ring system is present in numerous anti-parasitic, fungicidal, antiinflamatory drugs [2] , anti-hypertensive, anti $\neg$ viral, anti-tumour, anti-helminthic , anti-microbial,antioxidant, anti-ulcer, anti-amoebic, anti-histaminic activity, anti-bacterial, antipsychotic, antiprotozoal, antineoplastic, analgesic, anti dopaminergic, antihepatitis B virus, anticonvulsant, CNS depressant, anti-parkinson.
In addition, benzimidazoles are very important precursors in organic synthesis as (vitamin B12). Constituents are a milestone in the chemistry of benzimidazoles and antidiabetic activity (3-24).

Synthesis of benzimidazolyl chalcones which have been used as intermediate for the synthesis of bioactive heterocyclic compounds vis, pyrimidine-2,4,6-trione [25], thiazol-4-one [26], pyrazol-3-one [27], 1,7a-dihydro-pyrano [2,3-c] pyrazole-5-carbonitrile [28], thiazin2-yl-amine[29],1H-benzo[b][1,4]diazepine, benzocycloheptene and benzo[b][1,4] thiazepin 
[30], allylidene-hydrazide, 1,2 diazetidine-3carbonitrile, 1H-isoindol-2-yl, 4-morpholin-4-yl, 4-piperidin-1-yl, allylidene amino-propan-1-ol1,2-diol, which have high biological activity as antimicrobial and anticancer activity.

\section{Results and Discussion}

The new derivatives were prepared according to the reaction sequences depicted in Schemes 1 $\& 2$.

Nucleophilic addition of barbituric acid, thioglycolic acid with malononitrile and 3-Amino5-pyrazolinone [31] with 1-Biphenyl-4-yl-4-(1methyl-1H-benzimidazol-2-yl)-but-2-en-1-one (1) gave 5-[5-Biphenyl-4-yl-3-(1-methyl-1Hbenmidazol-2-yl)-5-oxo-pentyl]-pyrimidine2,4,6-trione (2), 5-[3-Biphenyl-4-yl-1-(1-methyl1H-benziomidazol-2-yl)-3-oxo-propyl]-2-methylthiazol-4-one(3),5-[1-Biphenyl-4-yl-1-(1-methyl1H-benziomidazol-2-yl)-allylidenamino]-2,4dihydro-pyrazol-3-one (4) which reacted with Arylidene malononitrile in ethanol to give 6-Amino-3-[1-biphenyl-4-yl-3-(1-methyl-1Hbenzoimidazol-2-yl)-alylideneamino]-4-(4methoxy-phenyl)-1,7a-dihydro-pyrano[2,3-c] pyrazole-5-carbonitrile (5).

Cyclocondensation of chalcone (1) with thiourea under reflux in dry ethanol in the presence of few drops of glacial acetic acid gave the corresponding 6-Biphenyl-4-yl-4-(1-methyl-1H-benzoimidazol2-yl)-5,6-dihydro-4H-[1,3] thiazin-2-yl-amine (6) and by treatment with bromine, acetic acid mixture afforded compound 6-Biphenyl-4-yl-5-Bromo-4-(1methyl-1H-benzoimidazol-2-yl)-6H-[1,3]thiazin-2yl-amine (7).

Similarly, cyclization of chalcone (1) with orthophenylinediamine in glacial acetic acid gives 4-Biphenyl-4-yl-2-(1-methyl-1H-benzoimidazol2-yl)-1H-benzo[b] $[1,4]$ diazepine $(8)$, by reaction of 3-Amino-5-pyrazolinone with chalcone (1) in ethanol containing T.E.A to form 5-Amino-4-[3biphenyl-4-yl-1-(1-methyl-1H-benzoimidazol-2ylmethyl)-3-oxo-propyl]-2,4-dihydro-pyrazol-3one (9). (Scheme 1).

Also, chalcone (1) reacted with 2cyanoacetohydrazide in acetic acid to form Schiff base cyano-acetic acid [1-biphenyl-4-yl3-(1-methyl-1H-benzimidazol-2-yl)-allylidene]hydrazide (10) and by heating in $96 \%$ acetic acid gave 2-[Biphenyl-4-yl-3-(1-methyl-1Hbenzoimidazol-2-yl)-allyl]-4-oxo-[1,2]diazetidine3 -carbonitrile (11), which upon reaction with phosphorous oxychloride gave 2-[1-Biphenyl-4yl-3-(1-methyl-1H-benzoimidazol-2-yl)-allyl]-4chloro-[1,2] diazetidine-3-carbonitrile (12) .

The latter compound reacted with $2^{\text {ry }}$ amines and yielded the substitueted amino diazetidine derivative(13a-c)2-[1-Biphenyl-4-yl-3-(1methyl-1H-benzoimidazol-2-yl)-allyl]-4-(1Hisoindol-2-yl)-[1,2]diazetidine-3-carbonitrile (13a),2-[1-Biphenyl-4-yl-3-(1-methyl-1Hbenzoimidazol-2-yl)-allyl]-4-morpholin-4-yl-[1,2] diazetidine-3-carbonitrile (13b) and 2-[1-Biphenyl4-yl-3-(1-methyl-1H-benzimidazol-2-yl)-allyl]-4piperidin-1-yl-[1,2]diazetidine-3-carbonitrile(13c), repectively.

On the other hand, the Schiff bases of 3[1-Biphenyl-4-yl-3-(1-methyl-1H-benziomidazol -2-yl)-allylidene amino] -propan-1-ol-1,2-diol (14) resulted from condensed compound (1) with 2- amino-2-(hydroxy methyl) propane- 1,3 diol in ethyl alcohol which reacted with phosphorous oxychloride to give [1-Biphenyl-4-yl-3-(1-methyl1H-benziomidazol-2-yl)-allylidene]-propyl-amine (15).

Finally, the cyclization of chalcone (1) with 2- aminophenol and 2-aminothiophenol in dry benzene formed 8-Biphenyl-4-yl-6-(1methyl-1H-benzoimidazol-2-yl)-5-oxo-9-azabezocycloheptene and 4-Biphenyl-4-yl-2-(1methyl-1H-Benzoimidazol-2-yl)-benzo[b][1,4] thiazepine $(16,17)$, repectively (Scheme 2$)$.

\section{Experimental}

Melting points were determined in open capillary tubes on an electrothermal 9100 digital melting point apparatus (Buchi, stritzerland) Elmer 2400 analyzer (USA).

IR spectra were recorded on a Perkin-Elmer 160 FTIR (USA) as KBr. The ${ }^{1} \mathrm{H}-\mathrm{NMR}$ and ${ }^{13} \mathrm{C}$-NMR spectra were measured on Brüker DRX 500 and $125 \mathrm{MHZ}$ at Max-Plank Institute, Germany in DMSO-d.

The elemental analysis were carried out at microanalytical, Faculty of Science, Cairo University by using Perkin-Elmer 2400 C, H, N elemental analyzer. 


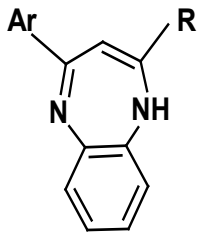

(8)<smiles>[R]C(CC([CH])=O)C1C(=O)NN=C1N</smiles><smiles></smiles><smiles>[Z17]C(=O)CC([R])C1C(=O)NC(=O)NC1=O</smiles>

(9)<smiles>[R]C1CC([Al])SC(N)=N1</smiles>

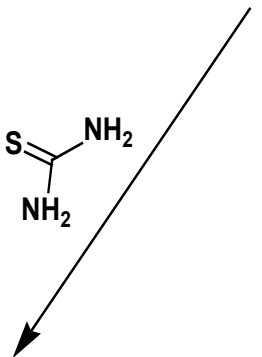

(6)<smiles>[R]C=C([Al])C1=C2C([Ge])=NNC2OC(N)=C1C#N</smiles>

(5)

(1)

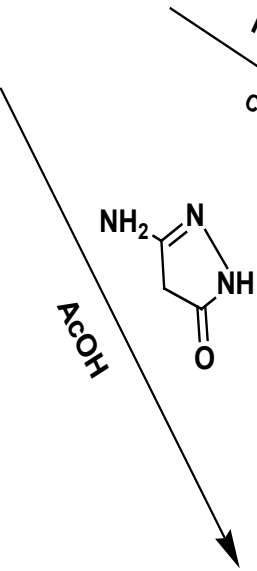

(2)<smiles>CC1=C(Br)C(Br)SC(N)=N1</smiles>

(7)

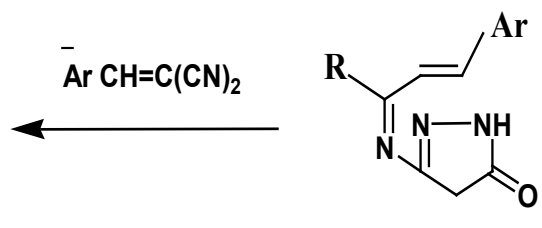

(4)

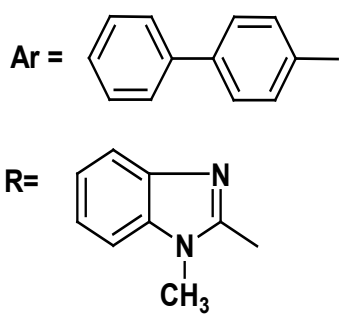

$\overline{\mathrm{A}} \mathrm{r}=\square-\mathrm{OCH}_{3}$

Scheme (1) 


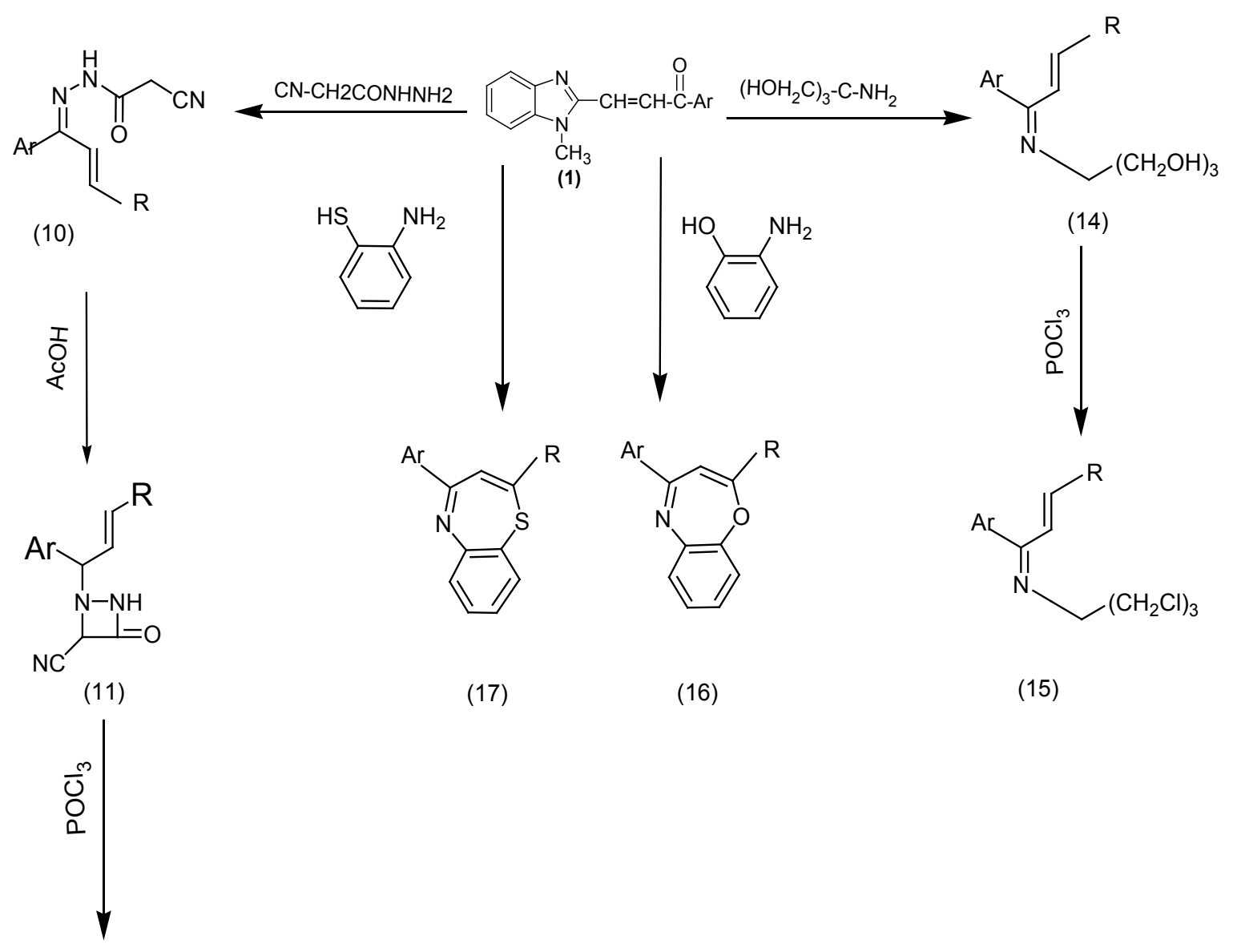

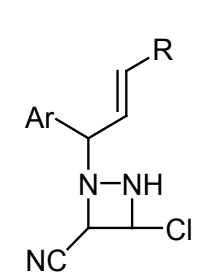

(12)
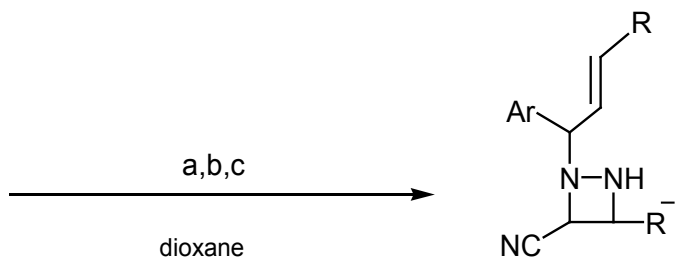

(13) a-c

$$
\bar{R}=\mathrm{a}=
$$

Scheme (2) 
Synthesis of 1-(Biphenyl-4-yl)-4-(1-methyl-1Hbenzimidazol-2-yl)- but-2-en-1-one (1)

To a solution of [4-(1H-benzimidazol-2-yl)-(1biphenyl-4-yl)-but-2-en-1-one] in methanol (20 $\mathrm{ml})$ is treated with methanolic sodium hydroxide solution (25 $\mathrm{ml} ; 20 \%)$ and then chloroacetic acid $(0.01 \mathrm{~mol})$ is added dropwise with continuous shaking. The reaction mixture is refluxed for $2 \mathrm{hr}$ and treated with dilute $\mathrm{HCl}$ and the solid obtained was recrystallized from benzene to give compound (1).

Synthesis of 5-[5-Biphenyl-4-yl-3-(1-methyl-1Hbenmidazol-2-yl) -5-oxo-pentyl]-pyrimidine- 2,4, 6- trione (2)

To a solution of (1) $(0.01 \mathrm{~mol})$ in dry benzene $(20 \mathrm{ml})$, Barbituric acid $(0.01 \mathrm{~mol})$ was added. The reaction mixture was refluxed for $10 \mathrm{hr}$, the solid separated on cooling was crystallized from ethanol to give (2). FT-IR (KBr,v, $\left.\mathrm{cm}^{-1}\right) 3406$, 3170 (2NH), 1624,1654,1685 $(2 \mathrm{C}=\mathrm{O},(\mathrm{C}=\mathrm{N}), 1558$ $(\mathrm{C}=\mathrm{C}), 1303\left(\mathrm{CH}_{3}\right) .{ }^{1} \mathrm{HNMR}$ spectrum DMSO d6), $3.8\left(\mathrm{~S}, 3 \mathrm{H}, \mathrm{CH}_{3}\right), 7.7-7.1(\mathrm{~m}, 15,2 \mathrm{CH}, \mathrm{ArH}), 10.2$ $(\mathrm{S}, \mathrm{H}, \mathrm{NH}), 13.8$ (S,H,NH), $1.5\left(\mathrm{dd}, 2 \mathrm{H}, \mathrm{CH}_{2}\right)$.

Synthesis of 5-[3-(Biphenyl-4-yl)-1-(1-methyl1H-benzimidazol-2-yl)-3-oxo-propyl]-4-oxo-4,5dihydro-2-methyl-thiazol-2-yl-acetonitrile (3)

To a solution of (1) (0.01 mole) and malononitrile $(0.01 \mathrm{~mol})$ and thioglycolic acid $(0.01 \mathrm{~mol})$ in ethanol $(50 \mathrm{ml})$ and acatalytic amount of pipredine was heated under reflux for $5 \mathrm{hr}$. The reaction mixture was cooled at room temperature and the solution was concentrated by evaboration of the solvent and then the product was collected and recrystallized from ethanol. FTIR $\left(\mathrm{KBr}, \mathrm{v}, \mathrm{cm}^{-1}\right) 1600(\mathrm{C}=\mathrm{O}), 1581(\mathrm{C}=\mathrm{C}), 1400$ (CH3 ), $2110(\mathrm{CN})$. The mass spectrum (EL/MS) shows molecular ion peak at $\mathrm{m} / \mathrm{z}=478(23 \%)$ and base peak at $\mathrm{m} / \mathrm{z}=190$.

Synthesis of 5-[1-Biphenyl-4-yl-1-(1-methyl1H-benziomidazol-2-yl)-allylidenamino]-2,4dihydro-pyrazol-3-one (4)

To a solution of compound (1) (0.01 mol) in acetic acid $(96 \%)$ was added 3-Amino-5pyrazolinone $(0.01 \mathrm{~mol})$. The reaction mixture was stirred at room temperature for 7 and $10 \mathrm{hr}$. The solid product which formed was filtered off, washed with water, air dried and recrystallized from absolute ethanol to give the title compound. FT-IR (KBr, v, $\left.\mathrm{cm}^{-1}\right) 3402(\mathrm{NH}), 1600(\mathrm{C}=\mathrm{O}), 1342$ (CH3). ${ }^{1} \mathrm{H}$-NMR spectrum (DMSO-d6), 3.3 $\left(\mathrm{S}, 3 \mathrm{H}, \mathrm{CH}_{3}\right), 7.5-7.1(\mathrm{~m}, 13 \mathrm{H}, \mathrm{Ar}-\mathrm{H}), 7.7-7.6$ $(\mathrm{dd}, 2 \mathrm{H}, \mathrm{CH}=\mathrm{CH}), \quad 2.4\left(\mathrm{~S}, \mathrm{H}, \mathrm{CH}_{2}\right),{ }^{13} \mathrm{C}-\mathrm{NMR} 25.1$ $\left(\mathrm{CH}_{3}\right), 192.4(\mathrm{C}=\mathrm{O}), 18.1\left(\mathrm{CH}_{2}\right), 82.2(\mathrm{CH}=\mathrm{CH})$.

Synthesis of 6-Amino-3-[1-biphenyl-4-yl-3-(1methyl-1H-benzoimidazol-2-yl)-alylideneamino]4-(4-methoxy-phenyl)- 1,7a-dihydro-pyrano [2,3c] pyrazole-5-carbonitrile (5)

To a solution of (4) $(0.01 \mathrm{~mol})$ and arylidene malononitrile $(0.01 \mathrm{~mol})$ in ethanol $(50 \mathrm{ml})$ on heating under reflux for $7 \mathrm{hr}$, the reaction mixture was cooled and the product was collected by filtration and recrystallized from petroleum ether (40-60). FT-IR (KBr, v, $\left.\mathrm{cm}^{-1}\right)$ $3417,3059(\mathrm{NH} 2, \mathrm{NH}), 2191(\mathrm{CN}), 1307\left(\mathrm{CH}_{3}\right)$, $1512(\mathrm{C}=\mathrm{C}), 1604(\mathrm{C}=\mathrm{N}), 1253(\mathrm{C}-\mathrm{O}), 1114$ (OCH3), The mass spectrum (EL/MS) shows molecular ion peak at $\mathrm{m} / \mathrm{z}=603 / 604 \mathrm{M} / \mathrm{M}^{+}$ $(3.9 \%)$ and base peak at $\mathrm{m} / \mathrm{z}=181$.

Synthesis of 6-Biphenyl-4-yl-4-(1-methyl-1Hbenzimidazol-2-yl)-5,6-dihydro-4H-[1,3] thiazin2-yl-amine (6)

To a solution of chalcone (1) $(0.01 \mathrm{~mol})$ and thiourea $(0.01 \mathrm{~mol})$ were dissolved in ethanolic $\mathrm{NaOH}(10 \mathrm{ml})$ stirred for $3 \mathrm{hr}$ by using a magnetic stirrer and then pored into $200 \mathrm{ml}$ water with continous stirring, this was kept in cold condition in refrigerator for $24 \mathrm{hr}$, the precipitate obtained was filtered, washed and recrystallized from ethanol to give (6). FT-IR (KBr, v, $\left.\mathrm{cm}^{-1}\right)$ 3421(NH2), $1608(\mathrm{C}=\mathrm{N}), 1423(\mathrm{CH} 3), \quad{ }^{1} \mathrm{H}$-NMR spectrum (DMSO-d6), ( $\delta, \mathrm{ppm}), 3.3$ (S,3H,CH3), 7.6-6.6 (m,14H, CH-thiazine, Ar-H), 7.8 (S,2H,NH2), 1.3 (dd, $2 \mathrm{H}, \mathrm{CH}_{2}$ - thiazine), 10.7 (S,H,CH- thiazine).

Synthesis of 6-Biphenyl-4-yl-5-Bromo-4-(1methyl-1H-benzimidazol-2-yl)-6H-[1,3]thiazin2-yl-amine (7)

A solution of (21) $(0.01 \mathrm{~mol}$, in glacial acetic acid $(20 \mathrm{ml})$ was stirred and treated portionwise with Bromine $(0.01 \mathrm{~mol})$ at $60-70{ }^{\circ} \mathrm{C}$. The solution was further stirred for $2 \mathrm{hr}$, then cooled in ice. The precipitate product was filtered, washed with light petroleum ether (40-60), stirred with concentrated ammonium hydroxide for $15 \mathrm{~min}$. The solid product was recrystallized from benzene to give (7). 3431 $\left(\mathrm{NH}_{2}\right), 1677(\mathrm{C}=\mathrm{N}), 1365\left(\mathrm{CH}_{3}\right), 706(\mathrm{Br})$.

Synthesis of 4-Biphenyl-4-yl-2-(1-methyl-1Hbenzoimidazol-2-yl)-1H-benzo[b] [1,4] diazepine (8)

To a solution of chalcone (1) $(0.01 \mathrm{~mol})$ and orthophenylene diamine $(0.01 \mathrm{~mol})$ in Dimethylformamide $(30 \mathrm{ml})$ containing added 
amount of glacial acetic are refluxed on water bath for 9-10 hr,then cooling down to room temperature, and the precipitate obtained is filtered and recrystallized from petroleum ether (60-80). FT-IR (KBr， v, $\left.\mathrm{cm}^{-1}\right)$ 3029(NH), 1300(CH3), $1599(\mathrm{C}=\mathrm{C}), 1659(\mathrm{C}=\mathrm{N})$, its ${ }^{1} \mathrm{H}-\mathrm{NMR}$ spectrum (DMSO-d6) reveals signals $(\delta, \mathrm{ppm})$ 7.7-6.8 (m,18H, Ar-H), $8.2(\mathrm{~S}, \mathrm{H}, \mathrm{NH}), 3.3\left(\mathrm{~S}, 3 \mathrm{H}, \mathrm{CH}_{3}\right)$, ${ }^{13} \mathrm{C}-\mathrm{NMR}, 22.5$ (CH3), 142.3-115.7 (Ar-c), 139.5 $(\mathrm{C}=\mathrm{N})$.

Synthesis of 5-Amino-4-[3-biphenyl-4-yl-1-(1methyl-1H-benzoimidazol-2-ylmethyl)-3-oxopropyl]-2,4-dihydro-pyrazol-3-one (9)

To a solution of 3-Amino-5-pyrazolinone $(0.01 \mathrm{~mol})$ in absolute alcohol $(15 \mathrm{ml})$ cotaining triethylamine $(0.5 \mathrm{ml})$ compound $(2)$ is added $(0.01 \mathrm{~mol})$, the reaction mixture was stirred at room temperature for 7 and $10 \mathrm{hr}$.

The solid formed after adding water $(20 \mathrm{ml})$ is filtered off, washed with water, air dried and recrystallized from absolute ethanol to give the title compound . FT-IR (KBr, v, $\left.\mathrm{cm}^{-1}\right)$ 1678,1620 $(2 \mathrm{C}=\mathrm{O}), 3250,3062\left(\mathrm{NH}_{2} \mathrm{INH}\right), 1381\left(\mathrm{CH}_{3}\right), 1527$ $(\mathrm{C}=\mathrm{C})$.

Synthesis of cyano-acetic acid [1-biphenyl-4-yl3-(1-methyl-1H-benzimidazol-2-yl)-allylidene]hydrazide (10)

To a solution of compound (1) $(0.01 \mathrm{~mol})$ in acetic acid $(10 \mathrm{ml})$ is added 2-cyanoacetohydrazide $(0.01 \mathrm{~mol})$.The reaction mixture is stirred at room temperature for $30 \mathrm{~min}$, the solid formed is filtered off, washed with water, air dried and recrystallized from absolute ethanol. FT-IR $\left(\mathrm{KBr}, \mathrm{v}, \mathrm{cm}^{-1}\right)$ 3186(NH), $1685(\mathrm{C}=\mathrm{O}), 1624(\mathrm{C}=\mathrm{O}), 1685,1624$ $(2 \mathrm{C}=\mathrm{O}), 1357(\mathrm{CH} 3)$, its $1 \mathrm{H}$-NMR spectrum (DMSO-d6), ( $\delta, p p m)$ 7.9-6.8 (m,13H,Ar-H), 13.9 $(\mathrm{S}, \mathrm{H}, \mathrm{NH}), 8.07(\mathrm{dd}, 2 \mathrm{H}, \mathrm{CH}=\mathrm{CH}), 3.3(\mathrm{~S}, 2 \mathrm{H}, \mathrm{CH} 2)$.

Synthesis of 2-[Biphenyl-4-yl-3-(1-methyl1H-benzimidazol-2-yl) -allyl]-4 - oxo -[1,2] diazetidine-3-carbonitrile (11)

Compound (10) $(0.01 \mathrm{~mol})$ is heated under reflux in acetic acid (96\%) for $5 \mathrm{hr}$, the reaction mixture was then concentrated to $1 / 2$ of its volume and left to cool at refrigerator. The product formed was collected by filtration, washed with water, air dried and recrystallized from ethanol. FT-IR (KBr, v, $\left.\mathrm{cm}^{-1}\right) .3280(\mathrm{NH}), 2130(\mathrm{CN}), 1662$ $(\mathrm{C}=\mathrm{O}), 1411(\mathrm{CH} 3), 1597(\mathrm{C}=\mathrm{C})$.

Egypt.J.Chem. Vol. 60, No.4 (2017)
Synthesis of 2-[1-Biphenyl-4-yl-3-(1-methyl$1 \mathrm{H}$-benzimidazol-2-yl)-allyl]-4-chloro-[1,2] diazetidine-3-carbonitrile (12)

A solution of compound (11) $(0.01 \mathrm{~mol})$ in phosphorus oxychloride $(50 \mathrm{ml})$ was heated under reflux for $3 \mathrm{hr}$, the reaction mixture was cooled and then poured into ice-water while stirring; the solid that formed was filtered off, washed with water ,air dried and recrystallized from ethanol to give (12). FT-IR (KBr, v,cm-1) $1620(\mathrm{C}=\mathrm{N}), 3414$ $(\mathrm{NH}), 1384(\mathrm{CH} 3), 744(\mathrm{Cl}) .1 \mathrm{H}$-NMR spectrum (DMSO-d6), reveals signals $(\delta, \mathrm{ppm}) \quad$ 7.6-6.8 $(\mathrm{m}, 14 \mathrm{H}, \mathrm{CH}, \mathrm{Ar}-\mathrm{H}), 7.7(\mathrm{dd}, 2 \mathrm{H}, \mathrm{CH}=\mathrm{CH}), 3.5(\mathrm{~S}, 3 \mathrm{H}$, $\mathrm{CH}$ ), 12.2 (S, H,NH), 13.7 (S,H,CH-diazetidine).

Synthesis of 2-[1-Biphenyl-4-yl-3-(1-methyl-1Hbenzimidazol-2-yl)-allyl]-4-(1H-isoindol-2-yl), 4-morpholin-4-yl and 4-piperidin-1-yl -[1,2] diazetidine-3-carbonitrile (13 a-c)

A solution of (12) and appropriate secondary amines $(0.01 \mathrm{~mol})$ in dry dioxane $(15 \mathrm{ml})$ containing few drops of triethylamine was refluxed until the material disappeared for 7-12 hr, the solvent was then evaporated till dryness and the resulting residue was triurated with water $(50 \mathrm{ml})$ and set aside overnight at refrigerator.The solid that formed is filtered off, and recrystallized from the proper solvent to give the title compounds. FT- $\mathrm{IR}\left(\mathrm{KBr}, \mathrm{v}, \mathrm{cm}^{-1}\right)$ 3417( $\mathrm{NH}), 1635(\mathrm{C}=\mathrm{N}), 1523(\mathrm{C}=\mathrm{C}), 1384\left(\mathrm{CH}_{3}\right)$. 2121 $(\mathrm{CN}), 1620(\mathrm{C}=\mathrm{N}), 1384(\mathrm{CH} 3), 1516(\mathrm{C}=\mathrm{C})$, $3414(\mathrm{NH}), 2121(\mathrm{CN})$.

Synthesis of 3-[1-Biphenyl-4-yl-3-(1-methyl-1Hbenzimidazol -2-yl)-allylidene amino]-propan-1ol-1,2-diol (14)

To a solution of (2) $(0.01 \mathrm{~mol})$ in acetic acid (96\%) (10 ml) is added to 2-amino-2-(hydroxy methyl) propane-1,3 diol (0.01 mol), and the solid formed is filtered off, washed with water , air dried and recrystallized from absolute ethanol. FT-IR $\left(\mathrm{KBr}, \mathrm{v}, \mathrm{cm}^{-1}\right)$ 1604(C=N), 1338(CH3), 3433-3302 (3 OH), its 1H -NMR spectrum (DMSO-d6),3.4(t, $\mathrm{H}, \mathrm{CH} 2 \mathrm{OH}), 3.7(\mathrm{dd}, 2 \mathrm{H}, \mathrm{CH} 2 \mathrm{OH}), 8.17 .2(\mathrm{~m}, 13 \mathrm{H}$, $\mathrm{ArH}), 9.8(\mathrm{~d}, 2 \mathrm{H}, \mathrm{CH}=\mathrm{CH}), 2.5(\mathrm{~S}, 2 \mathrm{H}, \mathrm{CH} 2), 13 \mathrm{C}-$ NMR , 56.1 (CH2OH), 23.1(CH3), 129.5-127.3 (Ar-C), $85.2(\mathrm{CH}=\mathrm{CH})$.

Synthesis of [1-Biphenyl-4-yl-3-(1-methyl-1Hbenzimidazol-2-yl)-allylidene]-propyl-amine (15)

A solution of compound (14) $(0.01 \mathrm{~mol})$ in phosphorus oxychloride $(50 \mathrm{ml})$ is heated under reflux for $3 \mathrm{hr}$, the reaction mixture is cooled down and then poured onto ice-water while 
stirring, the solid formed is filtered off, washed with water, air dried and recrystallized from ethanol to give (15). FT-IR (KBr, v, $\left.\mathrm{cm}^{-1}\right) 1620$ $(\mathrm{C}=\mathrm{N}), 1384(\mathrm{CH} 3), 759(\mathrm{Cl})$. The mass spectrum (EL/MS) shows molecular ion peak at $\mathrm{m} / \mathrm{z}=497$ $(2.8 \%)$ and base peak at $\mathrm{m} / \mathrm{z}=68$.

Synthesis of 8-Biphenyl-4-yl-6-(1-methyl- ${ }^{1} H-$ benzimidazol-2-yl)-5-oxo-9-aza-benzocy-cloheptene and 4-Biphenyl-4-yl-2-(1-methyl-1H-Benzimidazol2-yl)-benzo[b][1,4]thiazepine $(16,17)$

To a solution of compound (1) $(0.01 \mathrm{~mol})$ in dry benzene $(30 \mathrm{ml})$ is added to 2 - aminophenol and 2-aminothiophenol $(0.01 \mathrm{~mol})$ with drops of glacial acetic acid, the reaction mixtures is refluxed on the water bath (8-10 hr), the solids separated on cooling at room temperature, are recrystallized from ethanol to give the title compounds. FT-IR $\left(\mathrm{KBr}, \mathrm{v}, \mathrm{cm}^{-1}\right) 1431\left(\mathrm{CH}_{3}\right), 1696(\mathrm{C}=\mathrm{N}), 1111$ (C-O-C)., $1684(\mathrm{C}=\mathrm{N}), 1313(\mathrm{CH} 3), 1571(\mathrm{C}=\mathrm{C})$. its 1H-NMR spectrum (DMSO-d6), ( $\delta$, ppm) 2.5 (S,3H,CH3), 7.8-7.2 (m,17H,Ar-H), 8.2 (S, H, CHthiazepine)

\section{Biological Activity}

\section{Antimicrobial activity}

The antimicrobial activity of the synthesized compounds is determined in vitro using the disc diffusion [31].
All the synthesized compounds are screened for their antibacterial and antifungal activity in vitro by disc diffusion method using nutrient agar medium against following microorganisms, Staphylococcus aureus [ATCC 29213] Bacillus subtilis (Gram positive bacteria), Escherichia coli [ATCC 27853], Pseudomonas aeuroginosa [ATCC 25922] (Gram negative bacteria) and fungal species like Candida albicans, Aspergillus flavin organisms.

Ampicillin is used as a positive control for antibacterial screening and an Amphotericin B is used as a positive control for antifungal screening. DMSO (Dimethylsulfoxide) is diluent which does not affect the growth of microbes (negative control). The tested compounds were dissolved in (DMSO). Filter paper discs (Whatman, $5 \mathrm{~mm}$ diameter) were saturated with former solution for bacterial test. The saturated filter paper discs were placed on the surface of solidified Czapek's Dox agar dishes seeded by test bacterial and fungal strains. The inhibition zones were measured in $\mathrm{mm}$ at the end of an incubation period of $48 \mathrm{hr}$ at $28^{\circ} \mathrm{C}$. The screening results have been tabulated in Table 1 and represented in Fig. 1 \& 2 .

TABLE 1. Antimicrobial study of the newly synthesized compounds of Part (II)

\begin{tabular}{|c|c|c|c|c|c|c|}
\hline \multirow{3}{*}{ Comp. No. } & \multicolumn{4}{|c|}{$\begin{array}{c}\text { Antibacterial activity } \\
\end{array}$} & \multicolumn{2}{|c|}{ Antifungal Activity } \\
\hline & $\begin{array}{l}\text { GraI } \\
\text { B.subtilis }\end{array}$ & Se S.aureus & E.coli & Paeruginosa & \multirow{2}{*}{ A. flavin } & \multirow{2}{*}{ C.albicans } \\
\hline & \multicolumn{4}{|c|}{ Inhibition zone diameter $(\mathrm{mm})$} & & \\
\hline 1 & 10 & 6 & 11 & 8 & 10 & 12 \\
\hline 2 & 13 & 6 & 9 & 7 & - & -- \\
\hline 3 & 9 & 12 & -- & -- & 9 & 11 \\
\hline 4 & 11 & 7 & -- & 8 & 8 & 10 \\
\hline 5 & 12 & 9 & 10 & 10 & 11 & 9 \\
\hline 6 & 10 & 8 & - & -- & 12 & 10 \\
\hline 7 & 12 & 11 & 10 & 14 & - & - \\
\hline 8 & 16 & 11 & 16 & 12 & 9 & 11 \\
\hline 9 & 14 & 15 & 11 & - & 9 & 11 \\
\hline 10 & 10 & 12 & 12 & -- & - & 15 \\
\hline 11 & - & -- & - & - & 11 & 14 \\
\hline 12 & 16 & 9 & - & - & 13 & 16 \\
\hline 13 & 15 & 12 & -- & -- & 14 & 9 \\
\hline 14 & - & - & 11 & 10 & - & 16 \\
\hline 15 & 11 & 14 & 19 & 14 & 13 & 16 \\
\hline 16 & 13 & 10 & 11 & 13 & 12 & - \\
\hline Ampicillin & & & & & & \\
\hline $\begin{array}{c}\text { (antibacterial } \\
\text { drug) }\end{array}$ & 20 & 18 & 22 & 17 & - & - \\
\hline
\end{tabular}




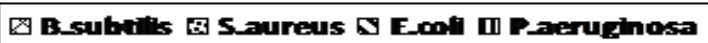

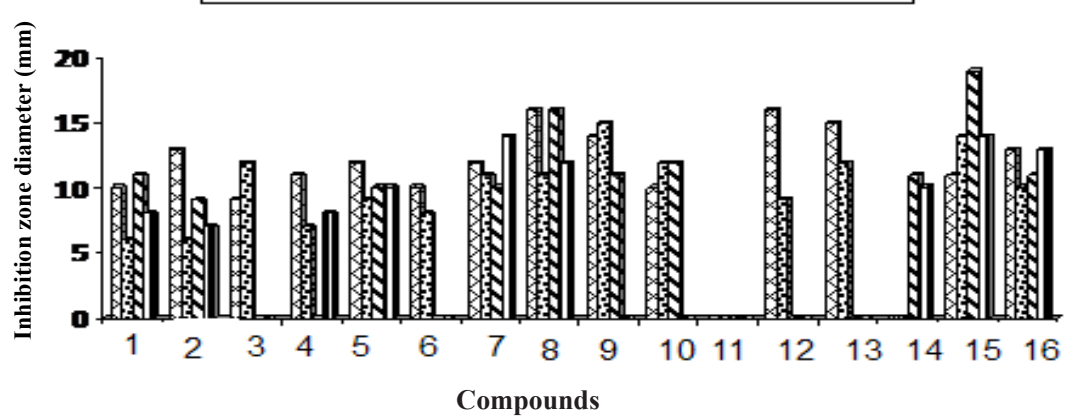

Fig.1 Antibacterial activity of newly synthesized compounds.

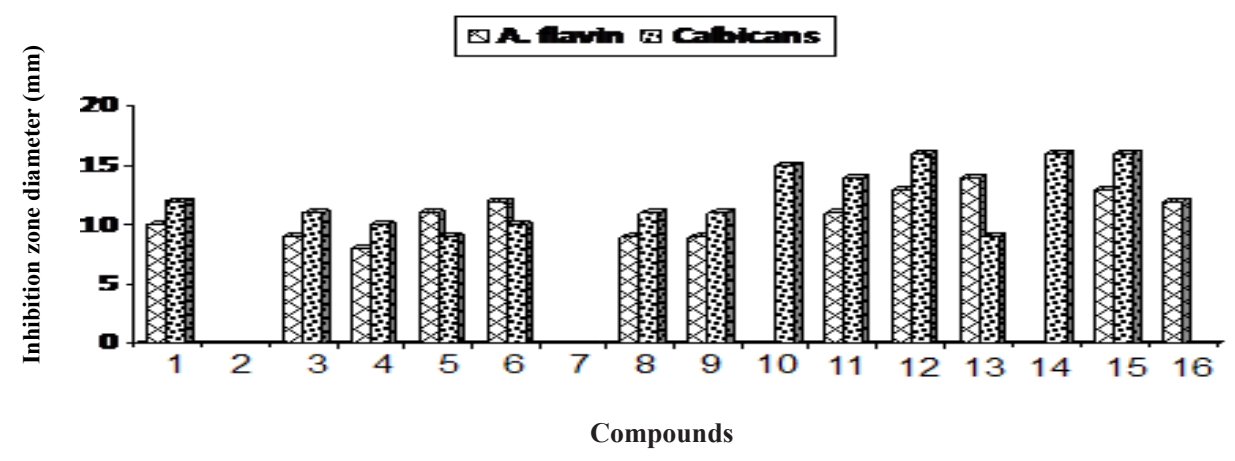

Fig.2 - Antifungal activity of newly synthesized compounds.

\section{Antiproliferative activity}

All the newly synthesized compounds were tested for antiproliferative activity in vitro against different types of cancer cell lines as (HEPG2) human liver carcinoma cell line, (MCF-7) human breast cancer cell line and (HCT-116) human colon cancer cell line at different concentrations (100, $50,25,12.5,6,25.0) \mathrm{ug} / \mathrm{ml}$, and the Doxorubicin, one of the most effective anticancer agents,was used as a reference drug. These cell lines were grown in RPMI -1640 medium supplemented with $2 \mathrm{mg} / \mathrm{ml}$ sodium bicarbonate, $4.5 \mathrm{mg} / \mathrm{ml}$ glucose, $100 \mathrm{ug} / \mathrm{ml}$ streptomycin sulphate ,40 $\mathrm{ug} / \mathrm{ml}$ gentamycin, $100 \mathrm{U} / \mathrm{ml}$ pencillin, as well as $10 \%$ (vol/vol) foetal bovine serum (FBS ). All cell lines incubated at $37{ }^{\circ} \mathrm{C}$ in humidified air containing $5 \% \quad \mathrm{CO}_{2}$. Cytotoxicity was determined by MTT (3-[4,5 $\neg$ dimethylthiazol-2yl]-2,5-diphenyltetrazolium bromide) is a water soluble tetrazolium salt, which is converted to an insoluble purple formazan by cleavage of the tetrazolium ring by succinate dehydrogenase within the mitochondria. The formazan product is impermeable to the cell membranes and therefore it accumulates in healthy cells [32] .

Breifly, the Plate cells (104-106 cells) in 200 $\mu 1$ PBS in 96-well (flat bottom). Add $20 \mathrm{ul}$ of MTT solution, mix well, incubate for $4 \mathrm{hr}$ in $37^{\circ} \mathrm{C}$ and incubate additional $1 \mathrm{hr}$ in $37^{\circ} \mathrm{C}$ in the dark. Then read plate in ELISA Reader - measure OD in 570 $\mathrm{nm}$ (background wavelength is $570 \mathrm{~nm}$ ). IC50\% $(\mu \mathrm{g} / \mathrm{ml})$, i.e. $(50 \%$ inhibition concentration) was calculated for the tested compounds by using (sigmaplot software). The results of the IC50\% of the compounds was tabulated (Table 2) and represented in Fig. 3.

\section{$\underline{\text { Results and Discussion }}$}

From Table 1, the results showed that all the compounds have moderate sensitivity towards Gram positive bacteria compared to positive control (Ampicillin) except the compounds (11, 
14) and all compounds showed slight to moderate sensitivity toward the Gram negative bacteria except $(3,4,6,9,11,12,13)$ which showed no antibacterial activity.

Antiproliferative activity of the newly synthesized compounds against human carcinoma cell lines Part (II): $\mathrm{IC}_{50} \%(\mu \mathrm{g} / \mathrm{ml})$ of newly synthesized compounds on human liver carcinoma cell line (HEPG2), human breast cancer cell line

(MCF-7) (Table 2 \& Fig.3).

\begin{tabular}{|c|c|c|}
\hline \multicolumn{3}{|c|}{ Inhibition concentration $(50 \%)\left(\mathrm{IC}_{50}\right) \mu \mathrm{g} / \mathrm{ml}$} \\
\hline Comp. No. & HEPG-II & MCF-7 \\
\hline 1 & 33.6 & 120.09 \\
\hline 2 & 63.6 & 103.22 \\
\hline 3 & 8.24 & 60.34 \\
\hline 4 & 12.81 & 8.51 \\
\hline 5 & 35.1 & 5.68 \\
\hline 6 & 57.9 & 95.02 \\
\hline 7 & 3.8 & 68.7 \\
\hline 8 & 20.2 & 21.5 \\
\hline 9 & 7.6 & 6.9 \\
\hline 10 & 10.3 & 125.5 \\
\hline 11 & 140.98 & 32 \\
\hline 12 & 45.3 & 87.2 \\
\hline 13 & 66.9 & 21.7 \\
\hline 14 & 23.3 & 34.2 \\
\hline 15 & 74.6 & 42.5 \\
\hline 16 & 49.7 & 11.2 \\
\hline
\end{tabular}

\section{图 HEPG-II 图 MCF-7}

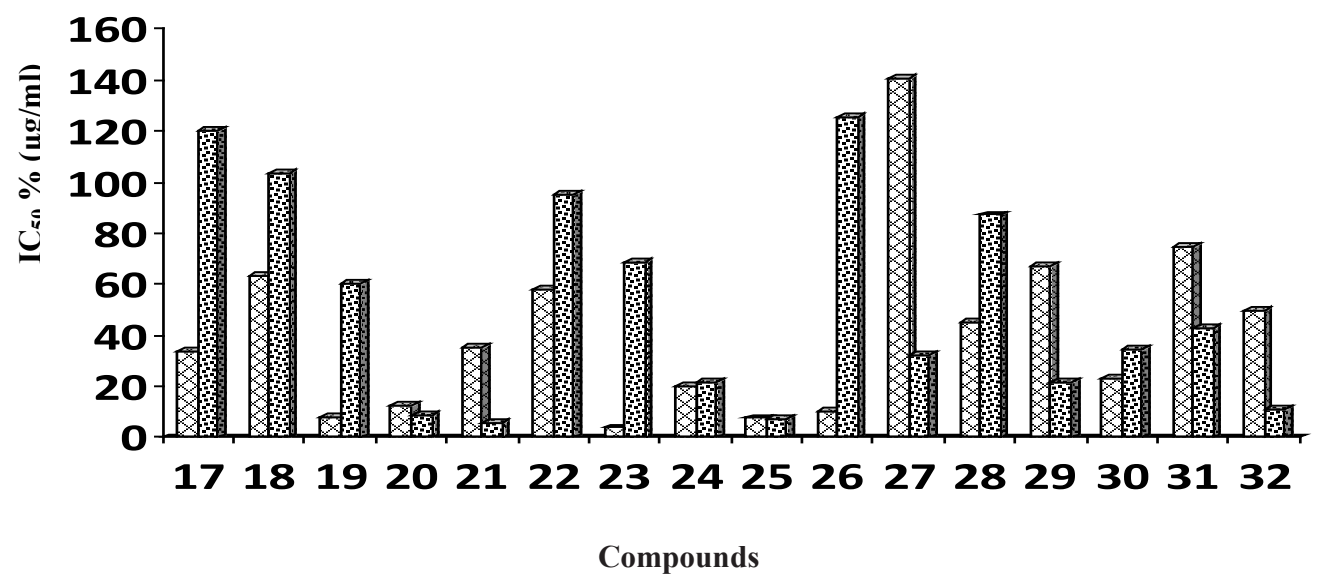

Fig. 3. Antiproliferative activity of the compounds against human carcinoma cell lines (HEPG2), (MCF-7). 
On the other hand, all compounds showed moderate to good antifungal activity towards (Candida albicans and Aspergillus flavin) except compounds $(2,7,10,14,16)$ which showed no antifungal activity compared to positive control (Amphotericin B).

From Table 2, the results showed that compounds $(7,9,2,10,3)$ were the most active recording IC $50 \%$ values in the order $(3.8,7.6$, $8.24,10.3,12.81) \mu \mathrm{g} / \mathrm{ml}$ against HEPG-II cell line. On the other hand,the compounds $(5,9,3,16)$ showed to be the most active recording IC $50 \%$ values in the order $(5.68,6.9,8.51,11.2) \mu \mathrm{g} / \mathrm{ml}$ against MCF-7 cell line.

\section{$\underline{\text { References }}$}

1. Zygmunt Kazimireczu, Jacqueline A. Upcroft, Peterupcroft, Agata Gorska, Bohdan Starosciak and Agnieszka Laudy, Synthesis, antiprotozoal and antibacterial activity of nitro- andhalogenosubstituted benzimidazole derivatives) Acta Biochimica Polonica, 49, No.1 ,185-195 (2002)

2. Ashish Kumar Tewari \& Anil Mishra, Synthesis and antiviral activities of N-Substitueted-2substitueted-benzimidazole derivatives), Indian Journal of Chemistry, Vol 54B, pp. 489-493 (2006)

3. Avinash Patil, Swastica Gangulgy and Sanjay Surana,(A Systematic review of Benzimidazole Derivatives as an Antiulcer Agent ). RJC Rasayan J. Chem, Vol.1 No.3,447-460. 2008

4. Michele Tonelli, Matteo Simone, Bruno Tasso, Federica Novelli,Vito Boido, Fabio Sparatore, Giueppepalietti,Sabrinaprcl, Gabriele Giliberti, Sylvain Blois, Cristina (Antiviral activity of benzimidazole derivatives. II. Antiviral activity of 2-phenylbenzimidazole derivatives,El SEVIER, 2937-2953. , (2010),

5. Vishvanath D. Patil, GoleMeha, Mhartre Shramesha, JaiswalAarti,(A mild and efficient synthesis of Benzimidazole by using lead peroxide under solvent free condition) peagia Research Library, (2010), 125-129.

6. SahooBiswa Mohan, Behera T.P. ,Ravi Kumar B.V.V., Microwave Irradiation Versus Conventional Method: Synthesis of Benzimidazolyl Chalcone Derivatives ), Chem. Tech (sep 2010),Vol 2 , No.3, pp.1634-1637.
7. Hanan M. Refaat, (Synthesis and Anticancer Actvity of Some Novel 2-Substituted Benzimidazole Derivatives). El SEVIER, (2010), 45, 2949-2956

8. DAVOOD AZARIFAR,MOJAN PIRHAYATI, BEHROOZ MALEK, MEHRANGIZ SANGINABADI and RAZIEH NEJAT YAMI, (Acetic acid-promoted condensation of o-phenylenediamine with aldehydes into 2-aryl-1(arylmethyl)-1H-benzimidazoles under microwave irradiation), Journal of the Serbian chemical society (2010),75 (9), 1181-1189.

9. Rondla Rohini, Kanneshnker, P. Muralidhar Reddy and Vadde Ravinder, ( Synthesis and Antimicrobial of a Activities New Class of 6-Arylbenzimidazo [1,2-c] quinazolines),J. Braz. Chem. Soc. (2010), Vol.21, N0.1,49-57.

10. Ramanpreet Walia, Ms. Hedaitullah, Syeda Farha Naaz, Khalid Iqbal and HS. Lamba., (BENZIMIDAZOLE DERIVATIVES - AN OVERVIEW) IJRPC (2011) .1 (3).

11. Parmendersingh Rathee, Ritu Dhakar, Sunny Bhardawaj, Monika Gupta and Rakesh Kumar, (Synthesis and Antimicrobial studies of novel Benzimidazole derivatives). Journal of Applied Pharmaceutical Science , 2011 , 01 (04) ,127-130.

12. Janardansingh Yadav and Y.K. Srivasta (Microwave assisted rapid and efficient synthesis, characterization and pharmacological evaluation of some novel benzimidazole assembled 1,5-benzodizepine and 1,5-benzothiazepine derivatives), Scholars Research Library , 2011, 3(2),284-291.

13. Ingle, R.G. and Magar, D.D. , (Heterocyclic Chemistry of Benzimidazoles and Potential Activities of Derivatives ) Jadoun Science, 2011,Vol.1,(1),26-32.

14. Fawzia Zakaria El- Aablack, (Synthesis of Some New Benzimidazole Derivatives of Pharmaceutical Interest). E-J.Chem. 8 (2), 748-752.(2011)

15. Ramesh Dhani, Gopnath Chakka, M.V. Saicharon Teja, P. Mastaniah, Avinash, P. Raja Rathnam, Saleha Naginas, K,V. Chadanasilpa, Dhana Lakshmik, (Synthesis and characterization of 2-mercaptobenzimidazole), I JAPAN, 1(3), 111$113(2011)$ 
16. P. Csontosh, S.,N. Pan deya, Ashishk.Pathak, (Benzimidazole : A Versatile Chemical Entity) IJAPAN (2011) , 2 (6) 1726-1737.

17. Sami Sajjadifar, Seyed Ahmed Mirshokraie, Nematollah Javaherneshan, Omid Louie (SBSA as a New and Efficient Catalyst for the One-Pot Green Synthesis of Benzimidazole Derivatives at Room Temperature), American, Journal of Organic Chemistry, 2012, 212 : 1-6.

18. Namratesingh, Annamaliapandurangan, Kavita Rana, preeti Anand, Arshad Ahmed, Amit Kumar Tiwari, (Benzimidazole: A short review of their antimicrobial activities), International Current Pharmaceutical Journal, 1(5) , 119-127 (2012)

19. Amanpreet S. Kohli, S.R. Wakode, (Synthesis of Some Benzimidazole Derivatives and Evaluation of their Antimicrobial Activity), International of pharmaceutical Frotier Research ,2 (2) , 56-67 (2012)

20. VAIDEHI , B.N.B. and GNANADEEPIKA, K. (Synthesis and Biological Evaluation of 2-Substituted Benzimidazoles), International Journal of Pharma and Bio Science, 3 (3) , p. 2631. (2012)

21. Chunxia Chen, Chen Chen, Binili, Jingwei Tao and Jinsongpeng, (Aqueous Synthesis of 1-H-2Substituted Benzimidazoles via Transition-MetalFree IntramolecularAmination of Aryl Iodides) Moecules , 17, 12506-12520 (2012)

22. Uday Kalidhar ,Rajinder Kumar, Aman Deep Kaur, (Synthesis, Spectral Studies and Biological Evaluation of Some Benzimidazole Derivatives containing Sulfonamide), Research Journal of Pharmaceutical Science, Vol (3) issue 2 Page No.1072.2012,

23. Nassir N. Al- Mohamed, Yatimah Alias, Zanariah Abdullah, Raied M. Shair, Ekhlass M.Taha and Aidil Abdul Hamid, (Synthesis and Antibacterial Evaluation of Some Novel Imidazoleand Benzimidazole Sulfonamides) , Molecules, 18, 11978-1995 (2013)

24. Singh Gurvinder, Kaur Maninderiit, Chander Mohan, (Benzimidazoles: The Latest Information on Biological Activities), International Research Journal of Pharmacy, 4 (1) (2013)

25. Hany J. Al-Najjar, Assem Barakat, Abdullah M.
Al-Magid,Yahia N. Mabkhot, Manuel Weber, Hazem A. Ghabbour and Hoong-Kun Fun (A Greener, Efficient Approach to Michael Addition of Baarbiturica acid to Nitrroalkenein aqueous Diethylamine Medium), ,Molecules, 19,1150-1162. (2014)

26. Marzoog S. Al-Thebeiti, raz (Synthesis of some new thiazolo[3,3-a]pyridines and related heterocyclic systems), ELSEVIER, ,55,109-118 (2000).

27. Mazaaheir Kidwai, Ruby Thakur, and Richa Mohan, (Ecofriendly Synthesis of Novel Antifungal (Thio) Barbituric Acid Derivatives), Acta Chim, 52, 8892(2005)

28. Ghodsi Mohammadi Ziarani, Sakineh Farmazi, Shima Asadi, Alireza Badiei, Roya Bazland Massoud Amalou,(Three-component synthesis of pyrano[2,3-d]-pyrimidine dione derivatives facilitated by sulfonic acid nanoporous silica (SBAPr- $\left.\mathrm{SO}_{3} \mathrm{H}\right)$ and their docking and urease inhibitory activity), DARU Journal Pharmaceutical Science, 1-13.(2013)

29. Gayathria Banda, S.M.H. Hipparagi, Ramjith,U.S, Cyril Mathews Jacob, (Microwave Assisted Synthesis of Fluoro, Chloro 2-Substituted Benzimidazole Thiazine Derivatives for Antibacterial and Analgesic.

30. Anshulchawla, Ramandeepkaur and Anju Goyal,( Importance of Microwave Reactions in the Synthesis of Novel Benzimidazole Derivatives) Journal of Chemical and Pharmaceutical Research , 925-944 (2011)

31.A.W.Bauer, W.W.M. Kirby,J.C. Sherris and M. Turck, (Antibiotic susceptibility testing by a standerized single disc method), 36 (3), 493-496. (1966)

32. T. Mosmann, (Rapid colorometric assay for cellular growth and survival: application to profilation and cytotoxicity assays, J.Imm).56,55-63. (1938)

(Received: 24/11/2015; accepted : $15 / 5 / 2016$ 
تحضير بعض المركبات الحلقية الغير المتجانسة عديدة الأنوية من1 -باى فينيل4--يل4--(-1ميثيل-بنزيميدازول2--يل)-بيوت- -2/ين1--

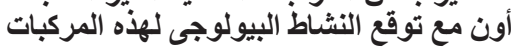

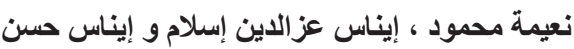

كلية العلوم - جامعة الأز هر - مدينة نصرو الهيئة المدائة المصرية للمصل وائن واللقاح ـ القاهرة - مصر

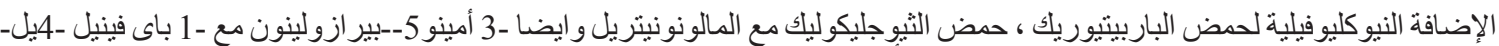

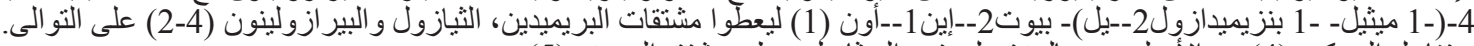

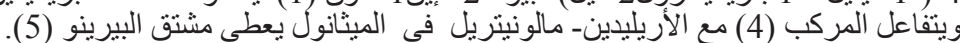

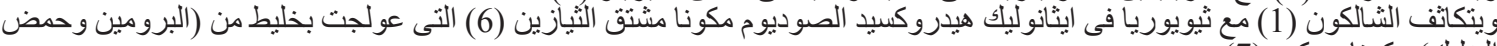

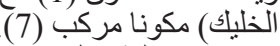

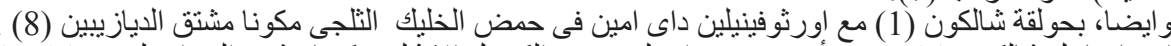

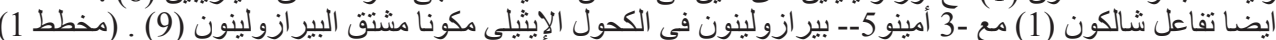

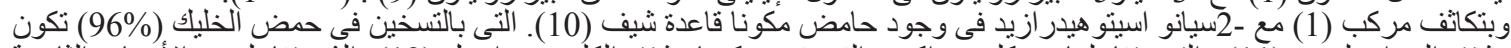

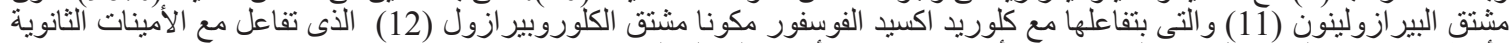

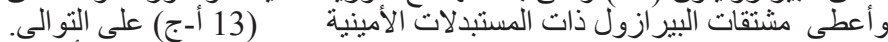

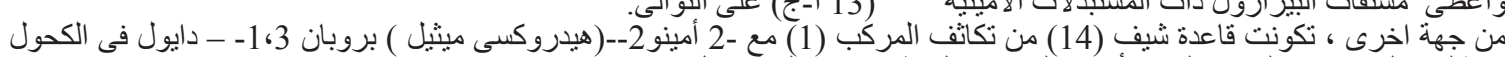

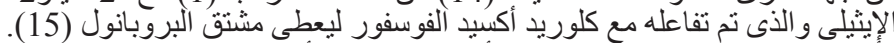

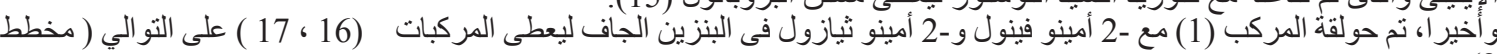

